\title{
REAKSI PASAR TERHADAP PERUBAHAN DIVIDEN DENGAN INDIKATOR ABNORMAL RETURN DAN TRADING VOLUME ACTIVITY
}

\author{
Adhe Raka Setiawan \& Bandi \\ Universitas Sebelas Maret Surakarta, Indonesia \\ Email: adhe.raka@gmail.com
}

\begin{abstract}
Abstrak: Reaksi Pasar Terhadap Perubahan Dividen dengan Indikator Abnormal Return dan Trading Volume Activity. Penelitian ini bertujuan untuk mengetahui reaksi pasar terhadap perubahan dividen, yaitu dividen tetap, dividen naik, dividen turun, dividen inisiasi, dan dividen omisi dengan indikator abnormal return dan trading volume activity pada perusahaan yang terdaftar di Bursa Efek Indonesia pada sektor properti, real estate, dan konstruksi bangunan periode 1998-2015. Penelitian ini menggunakan desain event study, di mana dilakukan pengamatan 5 hari sebelum dan 5 hari sesudah peristiwa. Analisis data yang digunakan dalam penelitian ini adalah Uji Paired Sample t-test. Hasil penelitian menunjukkan bahwa hanya dividen tetap dan dividen inisiasi dengan indikator trading volume activity terjadi reaksi pasar secara signifikan. Hasil penelitian ini juga menunjukkan bahwa untuk melihat reaksi pasar lebih baik menggunakan indikator trading volume activity dari pada abnormal return.
\end{abstract}

Kata kunci: dividen, abnormal return, trading volume activity.

\begin{abstract}
Market Reaction to Dividend Change with Abnormal Return and Trading Volume Activity as Indicators. The aim of this study is to find the influence of dividend change on market reaction, which are fixed dividend, rise dividend, fall dividend, initiation dividend, and omission dividend with abnormal return and trading volume activity as indicators at the companies listed in Indonesian Stock Exchange in property, real estate, and building construction sectors in 1998-2015. This study employs event study, in which it is observed within 5 days before and 5 days after the event date. Paired Sample t-test is utilized to analyze the data. The results show that fixed dividend and initiation dividend using average trading volume activity have significant effect on market reaction. Furthermore, it also suggests that to comprehend market reaction, trading volume activity is better indicator rather than abnormal return.
\end{abstract}

Keywords: dividend, abnormal return, trading volume activity.

\section{PENDAHULUAN}

Perusahaan yang tercatat di Bursa Efek Indonesia diklasifikasikan ke dalam sembilan sektor (sumber: http://www.idx.co.id, 2010). Salah satu sektor yang menarik perhatian adalah sektor properti, real estate, dan konstruksi bangunan. Sektor tersebut menarik perhatian dikarenakan jumlah penduduk Indonesia yang selalu mengalami peningkatan untuk setiap lima tahun (sumber: http://www.bps.go.id, 2015), dengan meningkatnya pertumbuhan penduduk Indonesia maka kebutuhan akan properti dan real estate juga mengalami peningkatan dan harga tanah yang selalu mengalami kenaikan seiring dengan waktu. Dalam mendirikan suatu bangunan dibutuhkan keahlian dari konstruksi bangunan, sehingga antara properti, real estate, dan konstruksi bangunan akan saling 
berhubungan satu dengan yang lainnya. Berdasarkan alasan tersebutlah investasi dalam sektor properti, real estate, dan konstruksi bangunan sangat menguntungkan dan menarik untuk dilakukan penelitian.

Informasi merupakan kebutuhan yang mendasar bagi para investor di pasar modal (Kurnianingsih, 2014). Salah satunya informasi yang dimaksud adalah informasi tentang pengumuman pembagian dividen. Dividen adalah bagian dari keuntungan perusahaan yang menjadi hak bagi pemegang saham disesuaikan dengan saham yang dimilikinya (Kurnianingsih, 2014). Investor akan menggunakan pengumuman dividen sebagai informasi untuk menilai harga saham perusahaan (Nugroho, 2014). Prosedur pembagian dividen akan mengakibatkan adanya perbedaan tanggapan antara para investor di dalam pasar modal. Hal ini diindikasikan dengan perubahan harga saham dan volume perdagangan saham perusahaan dari declaration date sampai dengan dividend payment. Apabila pengumuman dividen menimbulkan perubahan pada harga saham dan volume perdagangan saham, menandakan bahwa pengumuman dividen mengandung suatu informasi yang penting bagi investor. Reaksi pasar terhadap suatu peristiwa dapat diukur menggunakan indikator abnormal return dan trading volume activity, sesuai dengan pernyataan Ardiawan (2015) yang menyatakan bahwa reaksi pasar dapat diukur dengan melihat abnormal return saham yang diterima investor dan juga pada pernyataan oleh Susanti (2009) yang menyatakan bahwa volume perdagangan saham merupakan suatu indikator untuk mengukur reaksi pasar terhadap suatu pengumuman dengan menggunakan indikator trading volume activity.

Perubahan nilai pada dividen dalam penelitian ini dibedakan menjadi lima, meliputi: (1) dividen tetap, (2) dividen naik, (3) dividen turun, (4) dividen omisi, dan (5) dividen inisiasi. Berdasarkan teori signaling hypothesis, kenaikan nilai dividen dan nilai dividen yang tetap dianggap sebagai informasi yang baik (good news) sehingga pasar akan bereaksi positif, sedangkan untuk penurunan nilai dividen dianggap sebagai informasi yang buruk (bad news) sehingga pasar bereaksi negatif. Perusahaan yang menetapkan kebijakan membayar dividen pertama kali atau dividen inisiasi merupakan sinyal positif dan pasar cenderung akan bereaksi positif, sedangkan kebijakan perusahaan untuk menghapus pembayaran dividen pertama kalinya atau dividen omisi cenderung merupakan sinyal kurang baik sehingga pasar akan bereaksi negatif (Ghulam, 2012).

Telah dilakukan penelitian mengenai reaksi pasar terhadap pengumuman dividen tetapi hasil penelitian menunjukkan tidak konsisten antara satu penelitian dengan penelitian yang lain, oleh karena itu penelitian ini berfokus pada permasalahan adanya research gap dalam hasil beberapa penelitian dengan mengkonfirmasi pada teori signaling hypothesis yang dapat diuraikan sebagai berikut.

Penelitian Nugroho (2014) menyatakan bahwa tidak terdapat reaksi pasar sebelum dan sesudah pengumuman dividen tetap dengan indikator abnormal return tetapi hasil penelitian tersebut bertolak belakang dengan teori signaling hypothesis yang 
mengatakan bahwa nilai dividen dianggap sebagai informasi baik (good news) dan merupakan sinyal positif sehingga pasar akan bereaksi positif. Berdasarkan ketidaksesuaian hasil penelitian dengan teori signaling hypothesis dan untuk mencari bukti mengenai, adanya reaksi pasar terhadap dividen tetap dengan indikator rata-rata abnormal return, maka hipotesis pertama dalam penelitian ini adalah $\mathrm{H}_{110}$ : terdapat reaksi pasar terhadap dividen tetap dengan indikator rata-rata abnormal return.

Tidak ditemukan penelitian mengenai reaksi pasar terhadap dividen tetap dengan indikator trading volume activity selama peneliti melakukan observasi penelitian terdahulu dari beberapa sumber, sehingga peneliti menetapkan hipotesis kedua dengan mengkonfirmasi pada teori signaling hypothesis yang mengatakan bahwa nilai dividen yang tetap dianggap sebagai informasi baik (good news) dan merupakan sinyal positif sehingga pasar akan bereaksi positif ditunjukan dengan perubahan volume perdagangan saham serta untuk mencari bukti mengenai adanya reaksi pasar terhadap dividen tetap dengan indikator rata-rata trading volume activity. Dengan demikian hipotesis kedua penelitian ini adalah $\mathrm{H}_{210}$ : terdapat reaksi pasar terhadap dividen tetap dengan indikator rata-rata trading volume activity.

Penelitian Nugroho (2014) menyatakan bahwa terdapat reaksi pasar sebelum dan sesudah pengumuman dividen naik dengan indikator abnormal return, sedangkan Pratita (2013) menyatakan bahwa tidak terdapat pengaruh antara harga saham sebelum dan sesudah kenaikan dividen yang dapat diartikan bahwa tidak adanya reaksi pasar terhadap dividen naik. Berdasarkan hasil research gap penelitian terdahulu dan untuk mencari bukti tentang adanya reaksi pasar terhadap dividen naik dengan indikator ratarata abnormal return serta mengkonfirmasi pada teori signaling hypothesis, hipotesis ketiga penelitian ini adalah $\mathrm{H}_{120}$ : terdapat reaksi pasar terhadap dividen naik dengan indikator rata-rata abnormal return.

Azka (2013) mengatakan bahwa pada dividen naik tidak menyebabkan adanya perbedaan trading volume activity yang berarti pengumuman dividen naik tidak mengandung informasi yang penting sehingga pasar tidak bereaksi, sedangkan Ulfaizah (2014) menyatakan bahwa pada pembagian dividen kas naik terdapat reaksi pasar dengan indikator trading volume activity. Berdasarkan hasil research gap penelitian terdahulu dan untuk mencari bukti tentang adanya reaksi pasar terhadap dividen naik dengan indikator rata-rata trading volume activity serta mengkonfirmasi pada teori signaling hypothesis, hipotesis keempat penelitian ini adalah $\mathrm{H}_{220}$ : terdapat reaksi pasar terhadap dividen naik dengan indikator rata-rata trading volume activity.

Penelitian Putri (2014) menyatakan bahwa tidak terdapat reaksi pasar sebelum dan sesudah pengumuman dividen turun dengan indikator abnormal return, sedangkan menurut Pratita (2013) menyatakan bahwa terdapat pengaruh antara harga saham sebelum dan sesudah penurunan dividen yang dapat diartikan bahwa adanya reaksi pasar terhadap dividen turun. Berdasarkan hasil research gap penelitian terdahulu dan untuk mencari bukti tentang adanya reaksi pasar terhadap 
dividen turun dengan indikator rata-rata abnormal return serta mengkonfirmasi pada teori signaling hypothesis, hipotesis kelima penelitian ini adalah $\mathrm{H}_{130}$ : terdapat reaksi pasar terhadap dividen turun dengan indikator rata-rata abnormal return.

Putri (2014) mengatakan bahwa pada dividen turun tidak ada reaksi pasar dengan indikator trading volume activity, sedangkan Apriani (2005) menyatakan bahwa pada pembagian dividen kas turun terdapat reaksi pasar dengan indikator trading volume activity. Berdasarkan hasil research gap penelitian terdahulu dan untuk mencari bukti tentang adanya reaksi pasar terhadap dividen turun dengan indikator rata-rata trading volume activity serta mengkonfirmasi pada teori signaling hypothesis, hipotesis keenam penelitian ini adalah $\mathrm{H}_{230}$ : terdapat reaksi pasar terhadap dividen turun dengan indikator rata-rata trading volume activity.

Purwanto (2013) menyatakan bahwa pengumuman dividen inisiasi direspon positif oleh pasar sebelum dan sesudah pengumuman dividen dengan indikator abnormal return, sedangkan Astuti (2012) menyatakan bahwa tidak terdapat perbedaan rata-rata harga saham sebelum dan sesudah inisiasi dividen yang dapat diartikan bahwa tidak ada reaksi pasar terhadap dividen inisiasi. Berdasarkan hasil research gap penelitian terdahulu dan untuk mencari bukti tentang adanya reaksi pasar terhadap dividen inisiasi dengan indikator rata-rata abnormal return serta mengkonfirmasi pada teori signaling hypothesis, hipotesis ketujuh penelitian ini adalah. $\mathrm{H}_{140}$ : terdapat reaksi pasar terhadap dividen inisiasi dengan indikator rata-rata abnormal return.

Astuti (2012) mengatakan bahwa pada dividen inisiasi terdapat reaksi pasar sebelum dan sesudah pengumuman dividen dengan indikator trading volume activity, sedangkan Bukit dan Hartono (2000) menyatakan bahwa pengumuman pembayaran dividen (dividen inisiasi) dengan indikator trading volume activity pasar tidak bereaksi. Berdasarkan hasil research gap penelitian terdahulu dan untuk mencari bukti tentang adanya reaksi pasar terhadap dividen inisiasi dengan indikator rata-rata trading volume activity serta mengkonfirmasi pada teori signaling hypothesis, hipotesis kedelapan penelitian ini adalah $\mathrm{H}_{240}$ : terdapat reaksi pasar terhadap dividen inisiasi dengan indikator rata-rata trading volume activity.

Herdani (2015) menyatakan bahwa pengumuman dividen omisi tidak menunjukkan adanya abnormal return yang signifikan atau pasar tidak bereaksi, sedangkan Ghulam (2012) menyatakan bahwa terdapat perbedaan abnormal return sebelum dan sesudah dividen omisi yang dapat diartikan bahwa adanya reaksi pasar terhadap dividen omisi. Berdasarkan hasil research gap penelitian terdahulu dan untuk mencari bukti tentang adanya reaksi pasar terhadap dividen omisi dengan indikator rata-rata abnormal return serta mengkonfirmasi pada teori signaling hypothesis, hipotesis kesembilan penelitian ini adalah $\mathrm{H}_{150}$ : terdapat reaksi pasar terhadap dividen omisi dengan indikator rata-rata abnormal return.

Herdani (2015) mengatakan bahwa pada dividen omisi tidak terdapat kandungan 
informasi dengan indikator trading volume activity yang berarti bahwa pasar tidak bereaksi. Penelitian tersebut sesuai dengan teori signaling hypothesis yang mengatakan bahwa dividen omisi dianggap sebagai informasi buruk (bad news) dan merupakan sinyal negatif sehingga pasar akan bereaksi negatif. Berdasarkan uraian tersebut, peneliti ingin mengajukan pertanyaan apakah hasil penelitian tersebut dengan konfirmasi pada teori signaling hypothesis juga berlaku pada penelitian ini, sehingga hipotesis kesepuluh adalah $\mathrm{H}_{250}$ : terdapat reaksi pasar terhadap dividen omisi dengan indikator rata-rata trading volume activity.

\section{METODE}

Dalam bidang keuangan, event study digunakan untuk meneliti dampak suatu peristiwa seperti pengumuman dividen, right issue, stock split maupun peristiwa lainnya (Azka, 2013). Pada penelitian ini mengambil jenis penelitian event study, yang melakukan pengujian hipotesis tentang pengaruh dari suatu peristiwa tertentu pada perusahaan dengan titik kritisnya adalah pada saat tanggal pengumuman pembagian dividen. Penelitian ini menjelaskan hubungan antar variabel melalui analisis data untuk melakukan pengujian hipotesis. Event study penelitian ini merupakan study yang mempelajari harga saham dan volume perdagangan terhadap event pengumuman pembagian dividen untuk mengetahui apakah pasar bereaksi terhadap pengumuman dividen dengan jarak waktu lima hari kerja sebelum pengumuman dividen dan lima hari kerja setelah pengumuman dividen. Apabila dilihat dari hubungan variabel, maka hubungan yang terjadi adalah hubungan sebab akibat apabila $X$ (pengumuman dividen) maka $Y$ (reaksi pasar). Analisis data bersifat cross sectional, dikarenakan penelitian ini hanya mengambil kejadian dan sample waktu tertentu (Setyabudi, 2014).

Populasi adalah keseluruhan objek yang akan diteliti. Populasi dalam penelitian ini merupakan semua perusahaan yang terdaftar pada Bursa Efek Indonesia, sedangkan sampel merupakan sebagian dari populasi dengan karakteristiknya yang hendak akan dilakukan penelitian dan dapat dianggap mewakili dari keseluruhan populasi. Sampel perusahaan dalam penelitian ini menggunakan metode purposive sampling. Metode purposive sampling bahwa populasi yang akan dijadikan sampel adalah populasi yang memenuhi kriteria tertentu sesuai dengan yang dikehendaki oleh peneliti (Putri, 2013). Adapun kriteria sampel penelitian ini adalah (1) perusahaan yang tercatat dalam Bursa Efek Indonesia pada sektor properti, real estate, dan konstruksi bangunan; (2) cakupan waktu observasi perusahaan dalam penelitian ini dimulai tanggal 1 Januari 1998 sampai dengan 31 Desember 2015; (3) perusahaan melakukan pengumuman dividen minimal dua kali dalam periode pengamatan di Bursa Efek Indonesia sehingga dapat dilakukan pembagian kelompok dividen berdasarkan nilai dividen; (4) jenis data dividen yang digunakan adalah dividen tunai; (5) dividen inisiasi adalah pembayaran dividen tunai pertama kali setelah minimal dua kali berturut-turut tidak membayar dividen tunai selama periode pengamatan; dan (6) dividen omisi adalah penghapusan dividen tunai pertama kali 
setelah minimal dua tahun secara berturutturut melakukan pembayaran dividen selama periode pengamatan.

Sumber data dalam penelitian ini menggunakan data sekunder yang merupakan data yang diperoleh secara tidak langsung melalui perantara (Putri, 2013). Data diperoleh dari Bursa Efek Indonesia untuk jadwal pengumuman dividen dan nilai dividen, nilai IHSG dari www.finance.yahoo.com, harga saham harian perusahaan dan volume perdagangan harian perusahaan diperoleh dari aplikasi D'One Danareksa, dan jumlah total saham yang beredar pada perusahaan untuk setiap harinya diperoleh dari Pojok Bursa Efek UKDW. Analisis pengujian data untuk hipotesis penelitian ini menggunakan uji Paired Sample T-Test.

\section{HASIL DAN PEMBAHASAN}

Dividen tetap dengan indikator rata-rata abnormal return $\left(\mathrm{H}_{110}\right)$ menolak teori signaling hypothesis yang menyatakan nilai dividen tetap mengandung informasi yang bagus (good news) dan memberikan sinyal positif terhadap prospek masa depan perusahaan sehingga pasar bereaksi. Pada penelitian ini berkesimpulan bahwa pasar tidak bereaksi secara signifikan terhadap dividen tetap. Hal ini menunjukkan bahwa pasar tidak menjadikan pembagian dividen tetap untuk mengambil keputusan berinvestasi dan investor menganggap dividen tetap bukan sebagai good news, sehingga memilih untuk menunda rencana investasi dan menunggu perkembangan saham selanjutnya, ada kemungkinan investor memilih informasi lain sebagai pembuat keputusan. Hasil penelitian ini mendukung penelitian Nugroho (2014). Dividen tetap dengan indikator rata-rata trading volume activity $\left(\mathrm{H}_{210}\right)$ menerima teori signaling hypothesis yang menyatakan bahwa dividen yang bernilai tetap mengandung informasi yang bagus (good news) atau memberikan sinyal positif terhadap prospek masa depan perusahaan sehingga pasar bereaksi, pada penelitian ini berkesimpulan bahwa pasar bereaksi secara signifikan terhadap dividen tetap dengan indikator rata-rata trading volume activity. Hal ini menunjukkan bahwa pasar menjadikan pembagian dividen tetap untuk pengambilan keputusan berinvestasi dan investor menganggap dividen tetap sebagai good news, tetapi investor tidak mengutamakan pada harga saham tetapi berfokus pada jumlah saham. Kemungkinan investor membeli jumlah saham dengan volume besar dan menjualnya pada harga tidak terlalu tinggi tetapi pada volume yang besar meskipun begitu investor tetap akan tetap memperoleh keuntungan.

Dividen naik dengan indikator rata-rata abnormal return $\left(\mathrm{H}_{120}\right)$ dan rata-rata trading volume activity $\left(\mathrm{H}_{220}\right)$ menolak teori signaling hypothesis yang menyatakan bahwa peningkatan nilai dividen mengandung informasi bagus (good news) yang merupakan sinyal positif terhadap prospek masa depan perusahaan sehingga pasar akan bereaksi. Pada penelitian ini berkesimpulan bahwa pasar tidak bereaksi secara signifikan terhadap dividen naik. Hal ini menunjukkan bahwa pasar tidak menjadikan pembagian dividen naik dalam pengambilan keputusan berinvestasi dan investor menganggap dividen naik bukan sebagai good news sehingga memilih untuk menunda rencana 
investasi menunggu perkembangan saham selanjutnya, ada kemungkinan investor memilih informasi lain sebagai pembuat keputusan. Hasil penelitian ini mendukung penelitian Pratita (2013) dan menolak penelitian Nugroho (2014) untuk indikator abnormal return, sedangkan untuk indikator trading volume activity mendukung penelitian Azka (2013) dan menolak penelitian Ulfaizah (2014).

Dividen turun dengan indikator rata-rata abnormal return $\left(\mathrm{H}_{130}\right)$ dan rata-rata trading volume activity $\left(\mathrm{H}_{230}\right)$ menolak teori signaling hypothesis yang menyatakan penurunan nilai dividen mengandung informasi buruk (bad news) yang merupakan sinyal negatif terhadap prospek masa depan perusahaan sehingga pasar bereaksi negatif. Pada penelitian ini berkesimpulan bahwa pasar tidak bereaksi secara signifikan terhadap dividen turun. Hal ini menunjukkan bahwa pasar tidak menjadikan pembagian dividen turun dalam pengambilan keputusan berinvestasi, ada kemungkinan investor memilih informasi lain sebagai pembuat keputusan. Hasil penelitian ini mendukung penelitian Putri (2014) dan menolak penelitian Pratita (2013) untuk indikator abnormal return, sedangkan untuk indikator trading volume activity mendukung penelitian Putri (2014) dan menolak penelitian Apriani (2005).

Dividen inisiasi dengan indikator ratarata abnormal return $\left(\mathrm{H}_{140}\right)$ menolak teori signaling hypothesis yang menyatakan dividen inisiasi mengandung informasi baik (good news) yang merupakan sinyal positif terhadap prospek masa depan perusahaan sehingga pasar akan bereaksi. Pada penelitian ini berkesimpulan bahwa pasar tidak bereaksi secara signifikan terhadap dividen inisiasi. Hal ini menunjukkan bahwa pasar tidak menjadikan pembagian dividen inisiasi dalam pengambilan keputusan berinvestasi dan investor menganggap dividen inisiasi bukan sebagai good news sehingga memilih untuk menunda rencana investasi menunggu perkembangan saham selanjutnya, ada kemungkinan investor memilih informasi lain sebagai pembuat keputusan. Hasil penelitian ini mendukung penelitian Astuti (2012) dan menolak penelitian Purwanto (2013). Dividen inisiasi dengan indikator rata-rata trading volume activity $\left(\mathrm{H}_{240}\right)$ menerima teori signaling hypothesis yang menyatakan dividen inisiasi mengandung informasi yang bagus (good news) yang memberikan sinyal positif terhadap prospek masa depan perusahaan sehingga pasar bereaksi. Pada penelitian ini berkesimpulan bahwa pasar bereaksi secara signifikan terhadap dividen inisiasi dengan indikator rata-rata trading volume activity. $\mathrm{Hal}$ ini menunjukkan bahwa pasar menjadikan pembagian dividen inisiasi untuk pengambilan keputusan investasi dan investor menganggap dividen inisiasi sebagai good news, tetapi investor tidak mengutamakan pada harga saham dan berfokus pada jumlah saham. Kemungkinan investor membeli jumlah saham dengan volume besar dan menjualnya pada harga tidak terlalu tinggi tetapi dengan volume yang besar, meskipun begitu investor tetap akan memperoleh keuntungan. Hasil penelitian ini mendukung penelitian Astuti (2012) dan menolak penelitian Bukit dan Hartono (2000).

Dividen omisi dengan indikator rata-rata abnormal return $\left(\mathrm{H}_{150}\right)$ dan rata-rata trading 
volume activity $\left(\mathrm{H}_{250}\right)$ menolak teori signaling hypothesis yang menyatakan dividen omisi mengandung informasi yang buruk (bad news) yang merupakan sinyal negatif terhadap prospek masa depan perusahaan sehingga pasar bereaksi negatif. Pada penelitian ini berkesimpulan bahwa pasar tidak bereaksi secara signifikan terhadap dividen omisi. Hal ini menunjukkan bahwa pasar tidak menjadikan pembagian dividen omisi dalam pengambilan keputusan berinvestasi, ada kemungkinan investor memilih informasi lain sebagai pembuat keputusan. Hasil penelitian ini mendukung penelitian Herdani (2015) dan menolak penelitian Ghulam (2012) untuk indikator abnormal return, sedangkan untuk indikator trading volume activity mendukung penelitian Herdani (2015).

Hasil pengujian dari semua kategori dividen dapat diambil temuan yang baru bahwa dividen tetap dan dividen inisiasi (indikator rata-rata trading volume activity) lebih berharga bagi investor dibandingkan dengan dividen naik, turun, dan omisi. Penelitian ini juga mengambil temuan yang lain, untuk melihat reaksi pasar terhadap pengumuman dividen lebih baik menggunakan indikator rata-rata trading volume activity dibandingkan dengan menggunakan indikator rata-rata abnormal return. Berdasarkan pada hasil penelitian ini yang mengatakan apabila indikator rata-rata abnormal return menghasilkan nilai yang tidak signifikan, belum tentu indikator dari rata-rata trading volume activity juga menyatakan tidak signifikan. Rata-rata trading volume activity lebih mencerminkan reaksi pasar karena volume perdagangan akan terus berjalan seiring dengan transaksi yang terjadi, tidak peduli apakah harga saham mengalami kenaikan, penurunan, dan tetap. Sebagai contoh beberapa investor pada perusahaan $\mathrm{X}$ menjual harga sahamnya pada nilai offer Rp140,00 dengan jumlah saham 110.000 lot, sedangkan investor yang melakukan pembelian saham meletakan harga pada nilai bid Rp. 139 dengan jumlah saham 100.000 lot sehingga untuk menaikkan harga saham atau menurunkan harga saham senilai $\mathrm{Rp} 1,00$ harus menghabiskan jumlah saham yang berada pada bid (100.000 lot) atau offer (110.000 lot). Selama terjadi transaksi, volume perdagangan saham perusahaan akan mengalami peningkatan sedangkan harga saham akan tetap.

\section{SIMPULAN}

Penelitian ini menyimpulkan bahwa dividen tetap dengan indikator rata-rata abnormal return tidak terdapat reaksi pasar secara signifikan selama periode pengamatan lima hari sebelum dan lima hari setelah pengumuman dividen dan menolak teori signaling hypothesis. Dividen tetap dengan indikator rata-rata trading volume activity terdapat reaksi pasar secara signifikan selama periode pengamatan lima hari sebelum dan lima hari setelah pengumuman dividen dan mendukung teori signaling hypothesis.

Di saat dividen naik dengan indikator rata-rata abnormal return maupun trading volume activity, tidak terdapat reaksi pasar secara signifikan selama periode pengamatan lima hari sebelum dan lima hari setelah pengumuman dividen dan menolak teori signaling hypothesis. Kondisi yang sama juga terjadi di saat dividen turun dengan 
indikator rata-rata abnormal return atau trading volume activity, dividen inisiasi dengan indikator rata-rata abnormal return, dan dividen omisi dengan indikator rata-rata trading volume activity. Sedangkan dividen inisiasi dengan rata-rata trading volume activity terdapat reaksi pasar secara signifikan selama periode pengamatan lima hari sebelum dan lima hari setelah pengumuman dividen.

Penelitian ini juga menemukan bahwa dividen tetap dan dividen inisiasi dengan indikator rata-rata trading volume activity lebih berharga dibandingan dengan dividen yang lain, serta dalam menganalisis reaksi pasar lebih baik menggunakan indikator trading volume activity dibandingkan dengan indikator abnormal return.

Penelitian ini memberikan gambaran tentang reaksi pasar terhadap perubahan dividen, meliputi: (1) dividen tetap, (2) dividen naik, (3) dividen turun, (4) dividen inisiasi, dan (5) dividen omisi dengan indikator rata-rata abnormal return dan ratarata trading volume activity sehingga perusahaan dapat melihat pasar cenderung tidak menjadikan pengumuman dividen satusatunya dalam pengambilan keputusan untuk berinvestasi di dalam pasar modal.

Penelitian ini mengandung beberapa keterbatasan. Pertama, beberapa jumlah data perusahaan yang digunakan dalam penelitian ini tidak dimulai dari IPO perusahaan melainkan hanya perusahaan yang berada pada tahun 1998 - 2015 dikarenakan peneliti mengalami kesulitan dalam pencarian data. Kedua, penelitian hanya menguji pada perusahaan di sektor properti, real estate, dan kontruksi bangunan sehingga hasil penelitian ini belum dapat membandingkan antar sektor.

Guna penelitian lebih lanjut disarankan agar peneliti lain menggunakan jumlah data yang lebih besar dimulai dari IPO perusahaan sehingga data akan lebih akurat, dan menggunakan sektor lain sehingga dapat membandingkan antara sektor dalam melihat reaksi pasar terhadap dividen.

\section{DAFTAR PUSTAKA}

Apriani, L. (2005) "Reaksi Pasar Terhadap Pengumuman Kenaikan/Penurunan Dividen". Laporan Penelitian. Yogyakarta: Universitas Sanata Darma.

Ardiawan, D. (2015) "Analisis Kebijakan Harga Bakar Minyak (BBM) Oleh Pemerintah Terhadap Harga Saham". Laporan Penelitian. Surakarta: Universitas Sebelas Maret.

Astuti, T. D. (2012) "Uji Beda Harga Saham dan Volume Perdagangan Saham Pada Perusahaan IPO Yang Melakukan Inisiasi Dividen". Jurnal Sosiohumaniora, 3 (3), $33-43$.

Azka. (2013) "Analisis Pengaruh Pengumuman Dividen dan Ex - dividen Date Terhadap Perubahan Return dan Volume Perdagangan Saham". Laporan Penelitian. Yogyakarta: Universitas Gajah Mada.

Badan Pusat Statistik. (2015) Kependudukan dan Perumahaan. Diakses dari http://www.bps.go.id pada tanggal 21 Oktober 2015.

Bukit, dan Hartono, J. (2000). Reaksi Pasar Terhadap Dividend Initiations dan Dividend Omissions. Jurnal Simposium Nasional Akuntansi, 3, 931 - 956.

Bursa Efek Indonesia. (2010) Buku Panduan Indeks Harga Saham Bursa Efek Indonesia. Diakses dari 
http://www.idx.co.id pada tanggal 21 Oktober 2015.

Ghulam, M. (2012) "Analisis Perbandingan Reaksi Pasar Sebelum dan Sesudah Pengumuman Dividend Omissions". Laporan Penelitian. Surakarta: Universitas Sebelas Maret.

Herdani, I. R. (2015) "Pengujian Kandungan Informasi terhadap Pengumuman Omisi Dividen". Laporan Penelitian. Yogyakarta: Universitas Negeri Yogyakarta.

Kurnianingsih, H. (2014) "Analisis Reaksi Pasar Terhadap Pengumuman Dividen". Laporan Penelitian. Surakarta: Universitas Sebelas Maret.

Nugroho, K. A. (2014) "Analisis Reaksi Pasar Terhadap Pengumuman". Laporan Penelitian. Surakarta: Universitas Sebelas Maret.

Pratita, P. (2013) "Pengaruh Pengumuman Dividen dan Ex - dividen Date Terhadap Perubahan Return dan Volume Perdagangan Saham". Laporan Penelitian. Yogyakarta: Universitas Gajah Mada.
Purwanto, J. (2013) "Pengaruh Pengumuman Dividen Inisiasi Dan Dividen Omisi Terhadap Abnormal Return". Laporan Penelitian. Kepulauan Riau: Universitas Maritim Raja Ali Haji Tanjungpinang.

Putri, L.P. (2014) "Reaksi Pasar Terhadap Pengumuman Dividen Perusahaan Yang Listing Di BEI Dan Masuk Corporate Governance Perception Index". Laporan Penelitian. Jawa Timur: Universitas Brawijaya.

Setyabudi, F. H. (2014) "Pengaruh Perusahaan Keluarga, Ukuran Perusahaan, Profitabilitas, dan Kebijakan Utang Terhadap Kebijakan Dividen". Laporan Penelitian. Surakarta: Universitas Sebelas Maret.

Susanti, (2009) "Reaksi Pasar Terhadap Pengumuman Stock Split". Laporan Penelitian. Surakarta: Universitas Sebelas Maret.

Ulfaizah, R. (2014) "Analisis Reaksi Pasar Terhadap Kenaikan Dan Penurunan Dividen Kas". Laporan Penelitian. Yogyakarta: Universitas Islam Negeri Sunan Kalijaga. 